THE IMPACT OF MANDATORY IFRS ADOPTION ON FINANCIAL

ANALYSTS' EARNINGS FORECASTS IN SPAIN

Pascual Garrido Miralles

University of Alicante

Sonia Sanabria García

University of Alicante 


\section{THE IMPACT OF MANDATORY IFRS ADOPTION ON FINANCIAL ANALYSTS' EARNINGS FORECASTS IN SPAIN}

\section{INTRODUCTION}

The mandatory adoption of International Financial Reporting Standards (IFRS) by firms in the European Union since 2005 represents the greatest effort yet made to achieve full comparability between European firms and improve the transparency of financial reporting. The convergence of local standards with IFRS may have financial and accounting implications for analysts' earnings forecasts, among other matters.

Regulation No. 1606/2002 requires application of International Financial Reporting Standards (IFRS) by groups listed on European stock markets. In this context, the European Commission identifies enhanced comparability and increased transparency as important objectives in mandatory IFRS adoption for all listed firms starting from fiscal year 2005. This switch to IFRS reporting is probably the greatest change in reporting standards in history. One way to study how the switch in financial reporting contributes to these objectives is by studying the effect of mandatory adoption of IFRS on the financial information that analysts use to make earnings forecasts.

This study aims to contribute to evaluation of the benefits of IFRS mandatory adoption in Spain by investigating error and dispersion in analysts' forecasts around the time of adoption and the role of disclosures on the financial impact of IFRS. IFRS should provide financial analysts, the main users of financial information, with more detailed knowledge of firms' accounting strategies and practices, decreasing earnings forecast error and dispersion. In other words, the implementation of a more clear and understandable financial reporting following the implementation of IFRS should reduce divergences between analysts, causing a decrease in earnings forecast error and dispersion. The questions of interest are whether analysts have benefited from IFRS mandatory adoption and to what extent did firms' disclosures on the financial impact of IFRS assist analysts' forecasts? 
Mandatory adoption of IFRS represented a major change in the financial information reported by Spanish firms because some of the international standards differ considerably from Spanish GAAP (General Chart of Accounts of 1990). For example, goodwill is no longer amortised in accordance with IFRS 3 (Business Combinations) but is subject to impairment testing on an annual basis, where it was amortised over a maximum period of 20 years under Spanish GAAP. Under IFRS 39 (Financial instruments. recognition and measurement), meanwhile, financial derivatives are recognised at market value, and the effects of measurement are recognised in profit or loss, or in equity, depending on the classification of the derivatives. In contrast, Spanish GAAP treated financial derivatives as off-balance-sheet transactions, given that they have either a very small or no initial cost.

IFRS are closer to countries with an Anglo-Saxon accounting system, where professional practice takes the initiative in producing accounting rules. Therefore we are very interested in the impact of IFRS in Spain to be of interest as there is very little contribution from private initiative to accounting regulations, and accounting rules are normally issued by the public sector. For example, the general regulatory activity is carried out by the Institute of Accounting and Accounts Auditing (ICAC - Instituto de Contabilidad y Auditoría de Cuentas ), insurance company accounting is the responsibility of the Insurance Regulatory Authority (Dirección General de Seguros), the Bank of Spain regulates accounting for banks and credit institutions; accounting requirements for companies listed on the stock exchange are the competence of the Spanish Securities Exchange Commission (CNMV) and the State Intervention Office (Intervención General de la Administración del Estado) regulates public authority accounting.

Numerous studies examine the benefits arising from firms' adoption of IFRS from the standpoints of information quality gains and increased value relevance right through to enhancements in the efficiency of capital markets. Thus, Daske and Gebhart (2006) show that the amount and quality of the information disclosed is improved by the adoption of IFRS in three European countries (Austria, Germany and Switzerland). Meanwhile, Horton, Serafeim and Serafeim (2008) find an improvement in the reporting environment of non-financial European firms subject to mandatory IFRS adoption. Some papers also examine the impact of IFRS adoption on the cost of capital and agency costs (Leuz and Verrecchia, 2000; Hope, Kang and Zang, 2005; Karamanou and Nishiotis, 2009), while 
others provide evidence of institutional factors affecting voluntary adoption of IFRS (Hope, Jin and Kang, 2006). Armstrong, Barth, Jagolinzer and Riedl (2010) look at the market's reaction to IFRS adoption and other lines of research focus on the value relevance of financial information prepared using IFRS in different countries. This group of researchers includes Bartov, Goldberg and Kim (2005), Callao, Jarne and Laínez (2007), Hung and Subramanyam (2007), Horton and Serafein (2010), and Garrido and Vázquez (2011). These studies are important because they inform regulators and users of financial information alike about the potential benefits of IFRS adoption.

However, there are difficulties in adopting the IFRS accounting standard. Principles-based standards are stated as the dominant approach IFRS. Thus, in contrast to Rules-based standards, IFRS offer more reliance on professional judgment. Other opponents of the harmonization of accounting standards consider that national GAAP are the results of evolutionary processes (history, culture, institutional frameworks, systems of financing, etc) that generally make them better adapted to the particular circumstances of each country. Furthermore, Barth et al. (2008) point to two reasons why IFRS may be of lower quality than local accounting rules. Firstly, IFRS limit management's discretionary power over the choice of accounting options and they limit a firm's ability to choose the measures that best suit its interests. Secondly, if the level of enforcement for IFRS adoption is undemanding, it could eliminate any improvement in the quality of accounting standards.

Financial analysts perform a key task, acting as the intermediary between listed firms and investors, so the objective of this study is to examine how analysts have coped with the switch from Spanish GAAP to IFRS. We shall thus seek to establish how accurately these users of financial information forecast the earnings of firms when they apply IFRS. The period before and after mandatory IFRS adoption is especially significant for analysis of the impact of the changes on financial information analysts' forecasts.

To this end, we analyse a sample of 369 listed Spanish firms in the period 2003-2007, which applied IFRS for the first time as of 1 January 2005. The firms selected were all followed by at least two financial analysts in the period both before and after IFRS adoption. They applied Spanish GAAP in 2003 (the year prior to the transition to IFRS) and in 2004 (the transition year), and IFRS in 2005 (the adoption year) and in 2006 and 
2007 (post-adoption), when IFRS were fully applicable to all listed companies reporting consolidated financial statements. The evidence from the study shows a significant reduction in forecast error and dispersion after mandatory IFRS adoption.

The study contributes to the existing literature on the impact of IFRS adoption on analysts' forecasts in three ways. In the first place, this is an ideal moment for studies of this kind because IFRS adoption began in 2005, and it is now possible to observe the consequences of IASB standards for the transparency of financial information in the post-adoption period. Second, as far as we are aware, this is the first study in the Spanish capital market of the association between analysts' earnings forecasts and mandatory IFRS adoption. Third, our study provides information to financial analysts, regulators and other users of financial information with information on the causes and consequences of IFRS adoption for the purpose of earnings forecasting.

We focus this study on one particular country because it provides a constant and stable legal framework, institutional and corporate governance structure. Our study is consistent with Choi, Y-S, Peasnell, K. and Toniato, J. (2012) who indicate that such an approach concentrates on the effects of the change in standards more effectively than would be possible in an international comparison. In addition, Spain is particularly interesting as it did not allow for early voluntary adoption of IFRS unlike many other countries (before 2005, the use of IASB standards was allowed in France and Germany, for example). Spanish companies were required to adopt IFRS at the same time, thereby avoiding problems of selection bias which are present in samples of voluntary adopters (Ashbaugh, 2001).

Spanish accounting regulation is interesting due to the differences between Spanish GAAP, classified as a continental accounting model, and IFRS, closer to an Anglo-Saxon accounting model (Garcia Lara, Rueda and Vázquez, 2008; Callao, Ferrer, Jarne and Laínez, 2009). Specific differences between the two standards are reviewed in the Annex. In this regard, the institutional setting in Spain allows us to test whether mandatory adoption of IFRS, which is generally perceived to be more transparent, increases the comparability of reported accounting numbers across firms. Consequently, we examine the indirect effects of IFRS adoptionand we expect this change to lead to more reliable earnings forecasts 
from analysts. This improvement offers insights to regulators and policy makers as they make policy decisions to optimize institutional plans in their national capital markets.

The rest of this paper is structured as follows. Section two presents the existing literature and our hypotheses. The sample and the methodology employed are described in the third section. Section four reports the empirical results from our study, and section five contains a sensitivity analysis. Our conclusions are presented in section six.

\section{BACKGRUOUND AND HYPOTHESIS}

The aim of mandatory adoption of IFRS was to increase the amount of information disclosed in firms' financial statements and at the same time to reduce the available accounting options, thereby standardising disclosures to a greater extent. The reduction in the different IASB accounting options has evolved over time, with measures that have gradually limited the available options, providing better understanding of the information firms' supply, reducing error in accounting profit and disagreement between financial analysts under IFRS.

Comparability is an advantage for financial analysts as it increases their ability to forecast firms' results. In this regard, Daske et al. (2008) detect that the capital market benefits from mandatory IFRS adoption. De Franco et al. (2011) show that comparability reduces earnings forecast error and forecast dispersion

Previous literature on the impact of IFRS on earnings forecast error and forecast dispersion can be split into two basic groups of studies focusing on. 1) voluntary IFRS adoption and 2) mandatory IFRS adoption. The first studies in this line of research refer to countries that adopted IFRS voluntarily (e.g. France, Germany, Italy and Switzerland) and the empirical evidence obtained is mixed. Thus, Ashbaugh and Pincus (2001) find that analysts' earnings forecast error is smaller for firms that adopted IFRS than for those which stuck to local GAAP. Supporting this idea, Hope (2004) observes from a sample of firms in 18 different countries that the accuracy of earnings forecasts increases where the available accounting alternatives are more restricted. However, contrary evidence is reported by Daske (2005) and by Cuijpers and Buijink (2005). Examining a sample of 
German firms, Daske (2005) finds that analysts' earnings forecast error and dispersion are greater among IFRS adopters than among firms that continued to use German GAAP. Likewise, Cuijpers and Buijink (2005) observed higher dispersion in analysts' forecasts for firms using IFRS and US GAAP in a sample of European firms.

After 2005 papers belonging to the second group began to appear, examining the impact of mandatory IFRS adoption on analysts' earnings forecasts. Thus, Wang, Young and Zhuang (2008), Brown, Preiato and Tarca (2009) and Horton et al. (2010) who examine European firms, find that the accuracy of analysts' forecasts improved after the adoption of IFRS. For a sample of German firms, Glaum, Baetge, Grothe and Oberdörster (2011) associate IFRS adoption with an improvement in analysts' forecasts. In the same direction, Cotter, Tarca and Wee (2012) examine a sample of Australian firms, finding that IFRS improved analysts' earnings forecasts and that there were no significant changes in forecast dispersion in the year of IFRS adoption. Focusing on the level of enforcement and based on a sample of firms in the European Union, Byard, Li and Yu (2011) argue that analysts' forecast error and dispersion are lower for companies registered in countries where enforcement (regulatory control) is stricter and where the previously existing local standards are significantly different from IFRS. However, Tan, Wang and Welker (2011) maintain that the accuracy of local analysts' forecasts is not affected by the adoption of IFRS. Nevertheless, they observe a greater probability that firms adopting IFRS will be tracked by foreign analysts, which increases the accuracy of forecasts in the period following mandatory IFRS adoption.

During the study period (2003-2007) the Spanish accounting framework was replaced by an international one. The initial legislative measures governing this change were included in Law 62/2003, of 30 December 2003, on tax, administrative and social order measures (Spanish Official Gazette (BOE) Of 31 December 2003), which amended the legislation on individual and consolidated financial statements. In 2007, Law 16/2007 of 4 July continued with the general reform of the Spanish accounting system, introducing IFRS into Spanish accounting regulations. Finally, on 16 November, Royal Decree 1514/2007 was passed on the simplified regime for micro companies and came into force on 1 January 2008. 
Unlike other European countries (such as Austria, Belgium, Finland, France, Germany, Italy and Luxembourg) Spain did not permit voluntary use of IFRS. However, in countries with voluntary IFRS adoption there is weak evidence of improved forecasts after voluntary introduction of the international rules. As Cuijpers and Buijink (2005) point out, no significant differences were found in forecast dispersion between companies that voluntarily adopted IFRS and the companies that continued to use local accounting rules. Therefore we focus on analyzing mandatory adoption.Armstrong et al. (2010) find an increase in share prices around the date of IFRS adoption in Europe and attribute this improvement to increased comparability of financial information. Bae, Tan and Welker (2008) study 6,888 foreign analysts in 6,169 firms from 49 countries from 1998-2004 and conclude that accounting differences between countries represent a very high cost for financial analysts. Given that IFRS adoption can be expected to be useful and positive for capital markets and beneficial for users of financial information (and financial analysts in particular) because it increases harmonization of accounting practices and improves the information environment, we predict that IFRS adoption should reduce earning forecast error. As firms need time to adapt to the international regulations, we also attempt to verify whether financial analysts need time to understand the changes from local accounting principles to IFRS. Therefore, we posit:

H1. Analysts' earnings forecast error decreases after mandatory IFRS adoption.

Some of the arguments related to the proposals that mandatory IFRS adoption reduces analysts' forecast error are also valid for a reduction in forecast dispersion. A reduction in the number of discrepancies in accounting rules should reduce dispersion among financial analysts and forecast error. Given that IFRS adoption increases the comparability of financial statements and therefore reduces asymmetrical information and investor uncertainty in securities' markets (Yip and Young, 2012), we posit:

H2. Analysts' earnings forecast dispersion decreases after mandatory IFRS adoption.

Lang and Lundholm (1996) point out that the effects on forecast dispersion depends on whether differences in forecasts are due to private information or the forecast models the 
analysts use. That is, earnings forecasts may differ because analysts have different private information and so the increased information provided by IFRS would lead to less emphasis on private information, thereby decreasing forecast dispersion.

Even though the adoption of IFRS can be expected to provide benefits for the users of financial information, there are also a number of reasons why hypotheses H1 and H2 might not be accepted. Thus, Jermakowicz, Prather and Wulf (2007), Barth, Landsman and Lang (2008), and Landsman, Maydew and Thornock (2011) support the idea that high earnings volatility after IFRS adoption can increase analysts' earnings forecast error. Meanwhile the switch from local GAAP to IFRS may make it difficult for analysts to make reliable forecasts, at least temporarily, given the lack of initial familiarity with the international standards. This idea is supported by Cuijpers and Buijink (2005), who report that the expected benefits of IFRS adoption took some time to materialise.

\section{DATA AND METHODOLOGY}

\subsection{DATA}

In order to ascertain the impact of IFRS adoption on financial reporting by Spanish firms, we examine whether analysts' earnings forecasts error and dispersion have or have not improved the accuracy of predictions after mandatory IFRS adoption. We analyse a sample of listed Spanish firms in the period 2003-2007 in order to capture differences in analysts' earnings forecasts before and after mandatory IFRS adoption. This period is further broken down into four sub-periods, namely pre-transition to IFRS (2003), transition (2004), IFRS adoption (2005) and post-adoption (2006 and 2007). All firms in the sample close their annual accounts at 31 December.

Two dummies were used for the years prior to mandatory IFRS adoption to capture whether in the year immediately before adoption (i.e.2004) financial analysts discounted information on the effects that the change in accounting regulations would have on financial information (and on the accounting profit variable in particular). Although this study discards 13 observations which voluntarily introduced IFRS and we have restricted the sample to firms with "mandatory" IFRS introduction from 1 January 2005, financial 
analysts may have anticipated certain information and that may have reduced forecast errors in the yearly profits of firms before the introduction of IFRS.

The initial sample comprised 617 listed Spanish firms-years for the analysis period 20032007. Nevertheless, we delete 172 firms-years from this initial sample because they lack certain accounting data necessary for the analysis. We also exclude 13 firms-years from the initial sample that had already voluntarily adopted IFRS before 2005 as the focus of the study is mandatory IFRS adoption. Finally, we ensure minimum analyst coverage by discarding firms that are not covered by at least two financial analysts (63 firms-years) ${ }^{1}$. Consequently, the final study sample comprises 369 firms-years. The sample selection process is summarised in Table 1.

[Insert Table 1]

The dataset for analysts' earnings forecasts and the other variables used in the study are obtained from the Factset and Compustat data bases. We choose analysts' earnings forecasts closest to financial year end to ensure that all the predictions are made before earnings are published.

\subsection{RESEARCH DESIGN}

We use an Ordinary Least Squares (OLS) regression model $^{2}$ to test the hypotheses formulated for the study, including a set of control variables that may affect analysts' earnings forecast error and dispersion after the adoption of IFRS. We use Ordinary Least Squares to estimate a model with temporal "dummy" variables in order to capture the effect of introducing IFRS in profit forecasts (a common shock that affects all the firms in

${ }^{1}$ This restriction is necessary to capture dispersion in analysts' earnings forecasts.

${ }^{2}$ In view of the study objective, we think that a two-way panel model is appropriate, controlling simultaneously for fixed and temporary effects as follows:

$$
y_{i t}=\alpha_{i}+\gamma_{t}+\beta x_{i t}+\varepsilon_{i t}
$$

(which is equivalent to the model with dummy variables: $y_{i t}=a_{i}+\beta x_{i t}+F_{i}+T_{t}+\varepsilon_{i t}$, where $F_{i}$, are $(\mathrm{N}-1)$ individual dummy variables, $\mathrm{i}=2,3, \ldots, \mathrm{N}$, and $T_{t}$ are $(\mathrm{T}-1)$ temporary dummy variables, $\mathrm{t}=2,3, . ., \mathrm{T}-$ 1). The above model is estimated with an incomplete panel using the "Difference in difference" method, which requires units (in our case firms) in the two groups, known as treatment group (in our case firms that introduce IFRS) and comparison group (firms that do not introduce IFRS). In our sample all the firms simultaneously introduced IFRS and so it is impossible to estimate a two-way panel model. 
the sample). The database is an incomplete panel (not all temporal observations are available for all the firms in the sample).

Therefore, due to the design of our work (analysis of profit forecasts before and after IFRS introduction), the time dimension must be included and so linked section variability must be added (between companies). The only way panel data could be applied would be with two-way models and econometric software is currently unable to estimate these models with incomplete data.

All the variables in model are discussed in more detail below. The empirical model used is as follows ${ }^{3}$.

$$
\begin{aligned}
& A F E_{i, t}=\beta_{0}+\beta_{1} \text { Trans }+\beta_{2} \text { Adopt }+\beta_{3} \text { Post } 1+\beta_{4} \text { Post } 2+\beta_{5} \text { Lnsize }_{i, t}+\beta_{6} \text { Loss } \\
& +\beta_{7} \text { Time }+\beta_{8} \operatorname{Cov}_{i, t}+\beta_{9} \text { Cheps }_{i, t} \\
& F S D_{i, t}=\beta_{0}+\beta_{1} \text { Trans }+\beta_{2} \text { Adopt }+\beta_{3} \text { Post } 1+\beta_{4} \text { Post } 2+\beta_{5} \text { Lnsize }_{i, t}+\beta_{6} \text { Loss } \\
& +\beta_{7} \text { Time }+\beta_{8} \operatorname{Cov}_{i, t}+\beta_{9} \text { Cheps }_{i, t}
\end{aligned}
$$

Where:

$A F E_{i, t}$ is the absolute value error in analysts' earnings forecasts for firm i and year t, deflated by the share price at the end of year t. $A F E_{i, t}=\frac{\left|\left(E P S_{i, t}-F E P S_{i, t}\right)\right|}{P_{i, t}}$, where $E P S_{i, t}$ represents the earnings per share of firm i in year t, and $F E P S_{i, t}$ is the EPS forecast for firm $\mathrm{i}$ in year $\mathrm{t}$. $P_{i, t}$ is the share price of firm $\mathrm{i}$ at the end of year $\mathrm{t}$. $F S D_{i, t}$ is the standard deviation in analysts' EPS forecasts for firm i and year $\mathrm{t}$, deflated by the share price at the end of year $\mathrm{t}$.

PRETRANS is a dummy variable which takes a value of 1 for each observation in the year preceding transition to mandatory adoption of IFRS (2003) and zero otherwise.

\footnotetext{
${ }^{3}$ The PRETRANS variable is not in the regression to avoid exact multicolinearity problems.
} 
TRANS is a dummy variable which takes a value of 1 for each observation in the year of transition to mandatory adoption of IFRS (2004) and zero otherwise.

$A D O P T$ is a dummy variable which takes a value of 1 for each observation in the year of mandatory adoption of IFRS (2005) and zero otherwise.

POST is a dummy variable which takes a value of 1 for each observation in the years after mandatory adoption of IFRS (2006 and 2007) and zero otherwise. LNSIZE $_{i, t}$ is the logarithm of the market capitalisation of firm $\mathrm{i}$ at the end of year $\mathrm{t}$. LOSS is a dummy variable that takes a value of 1 if EPS for the current year is negative (loss-making firms) and zero otherwise.

TIME is the time interval between analysts' forecasts of annual earnings and the date on which actual earnings are published.

$C O V_{i, t}$ measures the number of analysts' earnings forecast for firm $\mathrm{i}$ in year $\mathrm{t}$ in the consensus forecast. It is a proxy for analysts' following.

CHEPS $_{i, t}$ is the absolute value of the difference between the EPS of firm $i$ in the current year ( $\mathrm{t}$ ) and EPS in the prior year ( $\mathrm{t}-1)$, deflated by the share price at the end of year t, so that $\operatorname{CHEPS}_{i, t}=\frac{\left|\left(E P S_{i, t}-E P S_{i, t-1}\right)\right|}{P_{i, t}}$.

The dependent variables considered in the study (AFE and FSD) are widely used in the literature. The share price is used as a deflator to facilitate comparison of analysts' earnings forecast error (AFE) and dispersion (FSD) (Lang and Lundholm, 1996; Byard et al., 2011). Forecast error refers to the difference between the EPS forecast and the real EPS value. Forecast dispersion refers to the standard deviation of analysts' forecasts from EPS. It is a proxy variable for information asymmetry. As Lang and Lundholm (1996) point out, dispersion is due to differences in the information analysts have, that is all analysts have the same public information, but each individual has access to certain private information. This difference in analysts' private information is the reason for forecast dispersion. In this regard, if IFRS provide homogenous information in greater detail, analysts' forecast dispersion is likely to reduce.

We include a number of control variables to account for factors affecting analysts' earnings forecast error and dispersion after the mandatory adoption of IFRS, such as firm size (Size) 
and analyst coverage (Cov). Size is measured in terms of stock market capitalisation. Large firms are expected to provide more additional information than their smaller peers, resolving some of the uncertainty about firms' future prospects, reflecting the future outlook for the business and thus reducing analysts' earnings forecast error and dispersion (Lang and Lundholm, 1996). However, it is more difficult to estimate the earnings of large firms, and mandatory IFRS adoption could therefore complicate the analysts' task, thereby increasing earnings forecast error and dispersion.

The number of financial analysts following a firm is also considered (Cov). It is expected that more information will be disclosed, forecast dispersion will be less and, therefore, analysts' forecast error will be less when more analysts follow a firm (Gu and Wu, 2003; Hodgdon et al., 2008). Consistent with Hodgdon et al. (2008), we predict a negative relationship between analyst following and forecast errors because more intense competition between analysts provides them with a greater incentive to reliably forecast future earnings. Although the expected relationship between analyst following and forecast dispersion is less clear (as there is a greater chance of a dissenting earnings forecast when more analysts are following a firm), we predict a negative relationship, reasoning that pressure for greater accuracy will also result in lower dispersion.

We also include variables such as changes in year-on-year earnings (Cheps) and a dummy for loss-making companies (Loss), which may be considered proxies for the level of difficulty of forecasting firms' earnings. The variable Cheps measures changes in earnings due to factors unrelated to IFRS. We include this variable to capture volatility in forecasts as a proxy for analysts' difficulty in making earnings forecasts for the firm. Similar to Lang and Lundholm (1996), we predict a decline in EPS forecast accuracy when there are major changes in earnings. The variable LOSS takes into account the fact that analysts are more likely to have issued forecasts that are found to have been especially optimistic when the firm reports a loss (Herrmann et al., 2008). Moreover, loss forecasts are less reliable than profit forecasts (Brown, 2001). We expect to observe larger forecast errors in earnings forecasts for loss-making firms.

We also control for the time period between the date of analysts' annual earnings forecasts and the date of publication of the actual earnings figures (Time). We include this variable to 
control for the tendency for earnings forecasts to become more reliable as the earnings announcement date approaches. Forecasts can be expected to be more reliable, with consequently smaller forecast error, the closer they are in time to the date earnings are published (Brown et al., 1999).

\section{RESULTS}

\subsection{DESCRIPTIVE ANALYSIS}

Table 2 shows the Spearman correlations between the variables used in the regression model. All the explanatory variables display a moderate correlation, indicating that each variable captures different information about analysts' earnings forecast error and dispersion, except in the case of the variables for firm size (Size) and number of financial analysts covering the firm (Cov). Given the high level of correlation found between these two variables (0.7929), it is necessary to control for the impact of firm size on analyst coverage. Rather than including the number of analysts covering a firm as a proxy of analyst coverage we include the residual part of the variable that is not explained by firm size. This proxy is obtained as the residual of the following regression (Forner and Sanabria, 2010).

$$
L O G(\text { Number of analysts })=c t e+\delta_{0} L O G(\text { size })+e
$$

[Insert Table 2]

Table 3 shows the evolution of the descriptive statistics for the dependent variables $\left(A F E_{i, t}\right.$ and $\left.F S D_{i, t}\right)$ in the different sub-periods considered in the analysis (Pretrans, Trans, Adopt and Post). As can be seen in Panel A, the mean of analysts' earnings forecast error (AFE) is higher in the pre-transition year (0.0290) when Spanish GAAP are still mandatory. In contrast, the lowest forecast dispersion is found in the post-transition period (2006 and 2007) when IFRS are mandatory. Panel C presents an univariate analysis. It shows that mean AFE are significantly greater in the pre-transition year than in the postadoption year and that the mean and median FSD are significantly lower in all years after 
the pre-transition IFRS period. Overall, these univariate tests suggest lower AFE and FSD in the post-adoption period, particularly when compared with the transition year.

Panel B of Table 3 shows that the highest mean and median for analysts' earnings forecast dispersion (FSD) are also found in the pre-transition year (0.0172 and 0.0111, respectively). Median dispersion in the post-transition period is the lowest for all four sub-periods although a slight increase in the mean was found in this period (0.0111).

[nsert Table 3]

Table 4 presents the descriptive statistics for the control variables used in our regression model. The mean year-on-year change in earnings is $5.82 \%$ for the pre-IFRS period and $3.82 \%$ for the post-IFRS period. Meanwhile, the mean number of analysts' forecasts per firm is similar for the pre and post-IFRS periods, around 12, and the mean time interval between analysts' forecasts of annual earnings and the date on which actual earnings are published is about 52 days for both periods. The mean size of the firms in the sample measured in terms of stock market capitalisation is $€ 7,203$ million for pre-IFRS period and $€ 7,634$ for the post-IFRS period, which is close to the median (7.364 and 7.677 respectively). Panel $\mathrm{C}$ show the $\mathrm{p}$-values of different tests of mean and median for control variables between the IFRS pre- and post-adoption periods. We find a statistically significant increase in firm size and time interval between analysts' forecasts of annual earnings and the date on which actual earnings are published, for all tests, both parametric and non-parametric.

[nsert Table 4]

\subsection{IMPACT OF IFRS ON ANALYSTS' FORECAST ERROR}

Table 5 shows the results of the regression analysis performed taking forecast error (AFE) as the dependent variable. We observe that analysts' earnings forecast error is significantly smaller in the period after IFRS adoption (Post) than in the periods prior to IFRS 
adoption, providing evidence in support of hypothesis $\mathrm{H} 1$ at a $5 \%$ level of significance ${ }^{4}$. This result was obtained after controlling for changes in earnings and the other explanatory variables. Consequently, as expected we find a negative relationship between analysts' earnings forecast error and improvements in the information disclosed in the financial statements after mandatory IFRS adoption.

The control variables included in the regression have their expected signs. We find a positive and significant association between analysts' earnings forecast error and the variable Loss $(\mathrm{p}$-value $=0.027)$, and between analysts' earnings forecast error and Cheps ( $\mathrm{p}$ value $=0.000)$. This result confirms that earnings forecast error is greater in loss-making firms and those displaying significant changes in earnings in two consecutive years, as these are the most difficult firms to earnings forecast. Bearing out the prior evidence, we observe that analysts' forecast error is lower in the case of firms covered by a larger number of analysts (Cov). Meanwhile, the size of firms (Lnsize) and the length of the time interval between analysts' forecasts of annual earnings and the date of publication of actual earnings (Time) are not statistically significant explanatory factors. The evidence observed for the size variable is similar to that found by Cotter et al. (2012).

[nsert Table 5]

We conclude that IFRS adoption benefits financial analysts' forecasts. However, these benefits take time to materialise and are not achieved immediately in the year of adoption. It seems that analysts come to know and understand IFRS better after a learning period in which they begin forecasting based on information prepared using international accounting standards. As our results show, greater understanding of IFRS leads to lower forecast error on the part of financial analysts.

When firms produce their financial statements following IFRS, there is evidence to show increased accounting comparability and better quality financial information (Jiao et al., 2012), financial analysts are able to make more reliable earnings forecasts, thereby reducing analysts' forecast error in the post-adoption period. Our conclusions are consistent with

\footnotetext{
${ }^{4} \mathrm{We}$ observe the results are the same when we the regression model includes the joined variable POST.
} 
the previous evidence found by Horton et al. (2008), mainly for Swiss and German firms, and by Wang et al. (2008), Brown et al. (2009), Byard et al. (2011), and Cotter et al. (2012) for firms in the European Union.

\subsection{IMPACT OF IFRS ON FORECAST DISPERSION}

Table 6 shows the results of the earnings' forecast dispersion (FSD) regression before and after mandatory adoption of IFRS. The coefficient of the variable Post1 is significantly negative as is the coefficient for the variable Adopt. Thus, dispersion in the analysts' earnings forecasts decreases from the moment of mandatory IFRS adoption (2005) and over the immediate post-adoption period. This result supports hypothesis H2.

Most of the explanatory variables in the regression are significant and have the expected signs. Also, we observe a positive and statistically significant relationship at $1 \%$ between analysts' earnings forecast dispersion and the variables Loss and Cheps. Therefore, we affirm that analysts' forecast dispersion is greater for loss-making firms and those with significant year-on-year changes in earnings. This result is consistent with Cotter et al. (2012). Finally, earnings' forecast dispersion is negatively associated with size and the number of analysts covering a firm, as expected.

\section{[Insert Table 6]}

\section{SENSITIVITY ANALYSIS}

The evidence described in the literature shows that analysts' earnings forecast error and dispersion are less when the quality of the audit firm is high (Behn, Choi and Kang, 2008). Indeed, it has been shown empirically that audits performed by the Big 4 firms increase the reliability of the financial information reported by firms (DeFond, M. L. and Jiambalvo, J., 1993; García, Garrido, Vico, Moizer and Humphrey, 1999). Therefore, it is likely that firms presenting the most reliable information will benefit from more reliable earnings forecasts.

Given this association between audit firms and the accuracy of analysts' forecasts, in this section we present an additional sensitivity analysis designed to test whether the impact of 
mandatory IFRS adoption changes in any way depending on a firm's auditor ${ }^{5}$. The total sample was split into two sub-samples for this purpose, the first containing firms audited by the Big 4 auditors, and the second containing firms audited by other (non-Big 4) auditors.

In general, the evidence points to the existence of incentives to report more reliable, better quality financial information that is less open to interpretation for firms audited by one of the Big 4 auditors. Meanwhile, the mandatory adoption of IFRS improves the quality and standardisation of the information. It may therefore be expected that the benefits of mandatory IFRS adoption will be greater for firms audited by one of the Big 4 auditors. This idea is tested in the sensitivity analysis shown in Table 7.

\section{[nsert Table 7]}

Panel A of Table 7 shows that analysts' forecast error is significantly smaller in the period following the adoption of IFRS only in firms that are audited by one of the Big 4 . We therefore conclude that the improvement in analysts' earnings forecasts (reduction in forecast error) observed in the total sample is led by firms that were audited by a Big 4 auditor.

Meanwhile, Panel B in Table 7 shows a significantly negative coefficient for the variables Adopt and Post, irrespective of the type of auditor. This result suggests that the auditor appointed by a firm does not influence the reduction observed in analysts' earnings forecast dispersion. The improvement in dispersion is therefore independent of the identity of firms' auditors, Big 4 or otherwise.

\footnotetext{
${ }^{5}$ Although is true that some aspects of the Big 4 variable is an approximation to the size variable, however, we consider that the Big 4 go further than that. As Choi and Wong (2007) point out auditors may plays a stronger governance role in weak legal environment, like Spain that have weak corporate governance mechanisms, and that high-quality auditor serves as a credible signal to reduce information asymmetry. In this sense, Verriest (2013) find that the association between Big 4 audits and earnings forecast properties is stronger in weak political environments.
} 
Based on the evidence obtained in this section, we conclude that firms audited by one of the audit majors significantly influence the improvement observed in analysts' forecasts following the adoption of IFRS. This would be consistent with the idea that the expected benefits and costs of IFRS adoption are not distributed randomly among Spanish firms.

\section{CONCLUSIONS}

Given the expectations placed on the adoption of IFRS, the regulatory effort involved and the cost to firms, it is necessary to verify empirically whether the expected benefits of the new international accounting system have been achieved. Earnings forecasts are taken as an indicator of the usefulness of financial statements to users of the information. Based on this idea, it is considered that financial analysts' earnings forecasts provide an opportunity to evaluate the impact of IFRS, as these earnings forecasts reflect firms' information environments and the quality of the information contained in the financial statements.

The main objective of this study is to investigate the impact of mandatory IFRS adoption in Spain on the earnings forecasts made by financial analysts, the main, but not the only users of financial information. In particular, the study focuses on the possible benefits of mandatory IFRS adoption for financial analysts covering firms in terms of information capture and the associated improvement in their earnings forecasts. For this purpose, we analyse a sample of 369 listed Spanish firms in the period 2003-2007.

There is little empirical evidence for financial analysts' earnings forecasts of listed firms in Spain in relation to IFRS and the benefits of mandatory IFRS disclosure standards, and as far as we are aware this is the first study to assess the impact of mandatory IFRS adoption on analysts' earnings forecast error and dispersion. Our study provides evidence on these issues, which will be of interest to market participants and others involved in evaluating this significant change. Our results should be of interest to users because they highlight the improvement in analysts' forecasts accuracy after IFRS adoption.

We find that mandatory IFRS adoption has had a significantly positive effect on the accuracy of financial analysts' earnings forecasts. We observe a lower level of analysts' forecast error after the change from Spanish GAAP to the international financial reporting 
standards, reflecting improvements in the quality of the financial information used by analysts. Moreover, our results show that analysts' earnings forecast dispersion decreases from the moment of mandatory IFRS adoption (2005) and over the whole of the postadoption period. However, we observe that financial analysts have more difficulty forecasting the earnings of loss-making firms and those with more pronounced year-onyear changes in earnings.

To sum up, although our study suggests that the transition process to IFRS has been beneficial for analysts following Spanish firms, the benefits of IFRS take time to materialize. In addition, the increase in forecast accuracy and decrease in forecast dispersion in the post-adoption year could result from additional effort and attention from preparers and analysts in producing, explaining and understanding IFRS results.

Our results also show that the expected benefits and costs of mandatory IFRS adoption in relation to financial analysts' forecasts are not randomly distributed among Spanish firms. We detect that the benefits obtained from the adoption of International Financial Reporting Standards in terms of analysts' earnings forecast error and dispersion are concentrated mainly in companies audited by the Big 4 audit firms. This result is consistent with the idea that firms which appoint one of the audit majors are likely to have the greatest incentives to present more reliable financial information that is less open to interpretation, which is the outcome achieved with the adoption of IFRS.

This study focuses on the effects of mandatory IFRS adoption on the accuracy of financial analysts' earnings forecasts in Spain. However, the results can be extended to other European countries as the Spanish accounting system is similar to the systems in Germany, France, Belgium, Austria and Italy (Garcia Lara, Rueda and Vázquez, 2008), as well as other countries applying continental European measurement, recognition and presentation rules for financial reporting. 


\section{REFERENCES}

Ashbaugh, H. 2001. Non-US firms' accounting standard choices. Journal of Accounting and Public Policy, 20 (2), 129-153.

Ashbaugh, H. and Pincus, M., 2001. Domestic accounting standards, international accounting standards, and the predictability of earnings. Journal of Accounting Research, 39(3), 417-434.

Armstrong, C., Barth, M., Jagolinzer, A. and Riedl, E., 2010. Market Reaction to the Adoption of IFRS in Europe. The Accounting Review, 85(1), 31-61.

Bae, K., Tan, H. and Welker, M., 2008. International GAAP differences: The impact on foreign analysts. The Accounting Review, 83 (3), 593-628.

Barth, M., Landsman, W.R. and Lang, M., 2008. International Accounting Standards and Accounting Quality. Journal of Accounting Research, 46(3), 467-498.

Bartov, E., Goldberg, S. and Kim, M., 2005. Comparative value relevance among German, US and International Accounting Standards a German stock market perspective. Journal of Accounting Auditing \& Finance, 20(2), 95-119.

Behn, B.K., Choi, J.H. and Kang, T., 2008. Audit Quality and Properties of Analyst Earnings Forecasts. The Accounting Review, 83(2), 327-349.

Brown, L.D., 2001. A temporal analysis of earnings surprises: profit versus losses. Journal of Accounting Research, 39(2), 221-242.

Brown, P., Preiato, J. and Tarca, A., 2009. Mandatory IFRS and Properties of Analyst Forecast: How Much Does Enforcement Matter?. Working Paper, University of Western Australia.

Brown, P., Taylor, S. and Walter, T., 1999. The impact of statutory sanctions on the level and information content of voluntary corporate disclosure. Abacus, 35(2), 138-162.

Byard, D., Li, Y. and Yu, Y., 2011. The Effect of Mandatory IFRS Adoption on Financial Analysts' Information Environment. Journal of Accounting Research, 49(1), 69-96.

Callao, S., Jarne, J. I. and Laínez, J. A., 2007. Adoption of IFRS in Spain: effect on the comparability and relevance of financial reporting. Journal of International Accounting, Auditing and Taxation, 16(2), 148-178.

Callao, S., Ferrer, C., Jarne, J.I. and Laínez, J.A. (2009): The impact of IFRS on the European Union. Is it related to the accounting tradition of the countries?. Journal of Applied Accounting Research, 10 (1), 33-55. 
Choi, J.H. and Wong, T.J., 2007. Auditors' governance function and legal environments: An international investigation. Contemporary Accounting Research, 24 (1), pp. 13-46.

Choi, Y-S, Peasnell, K. and Toniato, J., 2012. Has the IASB been successful in making accounting earning more useful for prediction and valuation? UK evidence. Working paper available at http://ssrn.com/abstract $=2116583$.

Cotter, J., Tarca, A. and Wee, M. (2012) IFRS Adoption and analysts' earnings forecasts: Australian evidence, Accounting and Finance, 52, pp. 395-419.

Cuijpiers, R. and Buijink, W., 2005. Voluntary adoption of non-local GAAP in the European Union: A study of determinants and consequences. European Accounting Review, 14(3), 487-524.

Daske, H., 2005. Properties of analysts' earning forecast in the process of transition towards International Financial Reporting Standards. Working paper, J.W. GoetheUniversität Frankfurt am Main, Germany.

Daske, H. and Gebhardt, G., 2006. International Financial Reporting Standards and Experts' Perceptions of Disclosure Quality. Abacus, 42(3-4), 462-498.

Daske, H., Hail, L., Leuz, C. and Verdi, R., 2008. Mandatory IFRS reporting around the world: Early evidence on the economic consequences, Journal of Accounting Research, 46 (5), 1085-1143.

DeFond, M. L. and Jiambalvo, J., 1993. Factors related to auditor-client disagreements over income-increasing accounting methods. Contemporary Accounting Research, 9(2), 415431.

DeFond, M., Hu, X., Hung, M. and Li, S., 2011. The impact of mandatory IFRS adoption on foreign mutual fund ownership: The role of comparability", Journal of Accounting and Economics, 51 (3), 240-258.

De Franco, G., Kothari, S.P. and Verdi, R.S., 2011. The Benefits of Financial Statement Comparability, Journal of Accounting Research, 49 (4), 895-931.

Forner, C. and Sanabria, S., 2010. Post-Earnings Announcement Drift in Spain and Behavioural Finance Models. European Accounting Review, 19(4), 775-815.

García, M.A., Garrido, P., Vico, A., Moizer, P. and Humphrey, C., 1999. La calidad del servicio de auditoría: Los auditores vistos por sus clientes. Revista Española de Financiación y Contabilidad, 102 (octubre-diciembre), 1005-1041. 
García Lara, J.M., Rueda Torres, J.A. and Vázquez Veira, P. J., 2008. Conservatism of earnings reported under International Accounting Standards: A comparative study. Revista Española de Financiación y Contabilidad, 138 (abril-junio), 197-210.

Garrido, P. and Vázquez, P.J., 2011., The Transition to IFRS in Spain: the Relevance and Timeliness of Adjustments. International Journal of Accounting, Auditing and Performance Evaluation, 7 (4), 287-302.

Glaum, M., Baetge, J., Grothe, A. and Oberdörster, T., 2011. Introduction of International Accounting Standards, Disclosure Quality and Accuracy of Analysts' Earning Forecasts. European Accounting Review, 1-38, forthcoming, DOI. 10.1080/09638180.2011.558301.

Gu, Z. and Wu, J.S., 2003. Earnings and Skewness and Analyst Forecast Bias. Journal of Accounting and Economics, 35(1), 5-29.

Herrmann, D., Hope, O-K and Thomas, W. 2008. International diversification and forecast optimism: The effects of Reg FD. Accounting Horizons, 22 (2), 179-197.

Hodgdon, C., Tondkar, R., Harless, D. and Adhikari, A., 2008. Compliance with IFRS disclosure requirements and individual analysts' forecast errors. Journal of International Accounting, Auditing and Taxation, 17(1), 1-13.

Hope, O-K., 2004. Variations in the Financial Reporting Environment and Earnings Forecasting. Journal of International Financial Management and Accounting, 15(1), 21-43.

Hope, O-K., Jin, J. and Kang, T., 2006. Empirical Evidence on Jurisdictions that Adopt IFRS. Journal of International Accounting Research, 25(2), 1-20.

Hope, O-K., Kang, T. and Zang, Y., 2005. The bonding hypothesis revisited. do crosslisting firm bond to the improved disclosure environment in the United States?. Working paper, University of Toronto and Singapore Management University.

Horton, J. and Serafeim, G., 2010. Market reaction and valuation of IFRS reconciliation adjutsments: first evidence from the UK. Review of Accounting Studies, 15(4), 725-751.

Horton, J., Serafeim, G and Serafeim, I. (2013): Does Mandatory IFRS Adoption Improve the Information Environment?, Comtemporary Accounting Research, 30 (1), 388-423.

Hung, M. and Subramanyam, K., 2007. Financial statement effects of adopting International Accounting Standards: the case of Germany. Review of Accounting Studies, 12(4), 623-657. 
Jermakowicz, E.K, Prather, J.J. and Wulf, I., 2007. The Value Relevance of Accounting Income Reported by DAX-30 German Companies. Journal of International Financial Management \& Accounting, 18(3), 151-191.

Jiao, T., Koning, M., Mertens, G. and Roosenboom, P., 2012. Mandatory IFRS adoption and its impact on analysts' forecast. International Review of Financial Analysis, 21, 56-63.

Karamanou, I. and Nishiotis, G.P., 2009. Disclosure and the Cost of Capital: Evidence from the Market's Reaction to Firm Voluntary Adoption of IAS. Journal of Business Finance \& Accounting, 36(7-8), 793-821.

Kent, P. and Stewart, J., 2008. Corporate governance and disclosures on the transition to International Financial Reporting Standards. Accounting and Finance 48(4), 649-671.

Landsman, W.R, Maydew, E.L. and Thornock, J.R., 2011. The Information Content of Annual Earnings Announcements and Mandatory Adoption of IFRS. Journal of Accounting and Economics, 1-21, forthcoming, DOI.10.1016/j.jacceco.2011.04.002.

Lang, M. and Lundholm, R., 1996. Corporate disclosure policy and analyst behaviour. The Accounting Review, 71(4), 467-492.

Law 62/2003, 30 December, Establishing tax, administrative and social measures.

Leuz, C. and Verrecchia, R. E., 2000. The economic consequences of increased disclosure. Journal of Accounting Research, 38 Supplement, 91-124.

Spanish General Chart of Accounts (1990) Royal Decree 1643/1990, 20 December, which approves the General Chart of Accounts.

Spanish General Chart of Accounts (2007) Royal Decree 1514/2007, 16 November, which approves the General Chart of Accounts

Tan, H., Wang, S. and Welker, M., 2011. Analyst Following and Forecast Accuracy After Mandated IFRS Adoptions. Journal of Accounting Research, 49(5), 1307-1357.

Verriest, A., 2013. Auditor Governance, Institutions and Analyst Forecast Properties: International Evidence. Journal of International Accounting Research In-Press. DOI: http://dx.doi.org/10.2308/jiar-50490.

Wang, X., Young, D. and Zhuang, Z., 2008. The Effects of Mandatory Adoption of International Financial Reporting Standards on Information Environments. Working paper presented at the American Accounting Association Conference, Anaheim, California.

Yip, R., and Young, D., 2012. Does Mandatory IFRS Adoption Improve Information Comparability?. The Accounting Review, 87 (5), 1767-1789. 


\section{ANNEX \\ DIFFERENCES BETWEEN SPANISH GAAP AND IFRS}

We have identified differences between Spanish GAAP and IFRS. These are related with IAS 12, income taxes; IFRS 3, business combinations; IAS 38, intangible assets; IAS 16 property, plant, and equipment; IAS 32 and 39, financial instruments; and IAS 37, provisions.

\section{Income taxes}

In accordance with 1990 Spanish GAAP, timing differences reflect differing criteria for the recognition of income and expenses for tax and accounting purposes. IFRS, however, introduce the concept of temporary differences between the carrying value of assets and liabilities and their tax base, generating prepaid and deferred tax assets and liabilities. 1990 Spanish GAAP did not set any limits on the recognition of deferred tax liabilities, while IAS 12 establishes certain restrictions. Though both IASs and 1990 Spanish GAAP restrict the recognition of deferred tax assets, the rules are different. As a consequence of the increase in the number of balance sheet items measured at fair value (held-for-sale financial assets and liabilities, financial assets and liabilities at fair value through profit and loss, etc.), more deferred tax assets and liabilities are recognised.

\section{Business combinations}

In accordance with IFRS 3, goodwill is no longer amortised and it is subject to impairment testing on an annual basis. 1990 Spanish GAAP allowed amortisation of goodwill over a maximum period of 20 years.

Under IFRS, firms recognising goodwill denominated in foreign currency translate balances into their local currency at the year-end exchange rate, while 1990 Spanish GAAP required conversion at historic rates of exchange.

\section{Intangible assets}

Under 1990 Spanish GAAP, start-up and other deferred expenses are capitalised and amortised on a straight-line basis over a maximum period of five years. These items must be treated as a current expense in accordance with IAS 38. In accordance with 1990 
Spanish GAAP, outstanding financial charges payable for leased operations were presented on the balance sheet through the deferred expenses account. In contrast, under IFRS such financial charges are treated as a reduction in the liability carried in the balance sheet. Share issuance expenses were eligible for capitalisation under 1990 Spanish GAAP and were amortised over a maximum period of five years. Under IFRS, these expenses are recorded against shareholders' equity, reducing the amount of the relevant capital increase. 1990 Spanish GAAP allowed the capitalisation of R\&D expenses and amortisation of the balance over a maximum period of five years. Under IFRS, research expenses must be recognised directly as an expense for the year, and only development expenses meeting certain criteria may be capitalised.

\section{Property, plant, and equipment}

Firms' adjustments to tangible fixed assets related to selective restatements permitted by IFRS 1, leased assets transferred to property, plant, and equipment and capital grants awarded for the purchase of tangible assets.

IFRS 1 allows selective restatement of certain property, plant, and equipment (land and buildings) based on appraisals performed by independent experts.

In accordance with IAS 17 (leases), the net value (i.e., cost less accumulated amortisation and, where appropriate, impairment provisions) of rights over leased tangible assets must be included in property, plant, and equipment.

In accordance with 1990 Spanish GAAP, any capital grants awarded for the acquisition of certain assets were recorded as a liability under deferred income. Under IFRS, however, these grants are deducted from the carrying value of the related (tangible or intangible) assets or recorded as deferred income.

\section{Financial instruments}

The main adjustments related to financial instruments refer to financial assets, financial derivatives, treasury shares, and expenses incurred in the issue of securities.

In accordance with 1990 Spanish GAAP, financial assets were measured at the lower of cost of acquisition or market value. Under IFRS, however, they are classified in a series of categories that determine subsequent measurement (fair value, amortised cost, etc.).

In accordance with IAS 39 (financial instruments: recognition and measurement), financial derivatives must be recorded at market value, and the effects of measurement are 
recognised through profit or loss, or through equity depending on the classification of the derivatives. 1990 Spanish GAAP treated financial derivatives as off-balance-sheet transactions, given that they have a very small or even no initial cost.

Under 1990 Spanish GAAP, the gains or losses arising from transactions with treasury shares were recognised as extraordinary income or expenses. Under IFRS, however, the results of treasury stock transactions are recognised through equity. Treasury shares reduce equity under IFRS. Spanish GAAP classified expenses incurred on the issue of financial instruments and the difference between the repayment value and the value of the assets received upon contracting certain types of financing operations as deferred expenses. These deferred expenses were reclassified in accordance with IAS 39, however, by reducing the carrying value of the originating financial liability, they are measured at amortised cost.

\section{Provisions}

The criteria established for the recognition of provisions under IASs are stricter than in 1990 Spanish GAAP. Thus, IAS 37 requires that a provision be recognised when:

a) an entity has a present obligation

b) it is probable that an outflow of resources embodying economic benefits (normally cash) will be required to settle the obligation

c) the amount of the obligation can be reliably estimated. On this basis, certain general provisions recorded by Spanish firms under 1990 Spanish GAAP were cancelled against reserves upon the application of IAS 37.

Firms also commonly made adjustments to reflect the effect of calculating the present value of certain provisions in accordance with IAS 37, which requires that provision be made for the net present value of best estimates of the amount required to cancel the obligation in question at an appropriate discount rate. 
Table 1

Sample selection

Number of firms-years

\section{INITIAL SAMPLE}

Eliminated.

Firms with insufficient data for analysis

Firms that adopted IFRS voluntarily

Firms followed by fewer than 2 financial analysts

FINAL SAMPLE

369

This table shows the sample selection process. The final study sample is obtained after eliminating all firmsyears for which the necessary data for the regression analysis is unavailable, as well as firms-years that had already adopted IFRS voluntarily or are followed by fewer than two financial analysts. 
Table 2

Spearman correlations for the variables included in the multivariate regression analysis

\begin{tabular}{lllllll}
\hline & Cheps & Lnsize & Time & Cov & AFE & FSD \\
\hline Cheps & 1 & & & & \\
Lnsize & $-0.1623^{* *}$ & 1 & & & & \\
& $(0.0018)$ & & & & & \\
Time & 0.0356 & $-0.2563^{* * *}$ & 1 & & \\
& $(0.4952)$ & $(0.0000)$ & & & \\
Cov & -0.1232 & 0.7929 & -0.1468 & 1 & 1 \\
& $(0.0178)^{* *}$ & $(0.0000)^{* * *}$ & $(0.0047)^{* *}$ & & \\
AFE & 0.7058 & -0.1286 & 0.0361 & -0.1202 & 1 \\
& $(0.0000)^{* * *}$ & $(0.0134)^{* *}$ & $(0.4883)$ & $(0.0209)^{* *}$ & \\
FSD & 0.4213 & -0.2294 & 0.1161 & -0.1895 & 0.4533 \\
& $(0.0000)^{* * *}$ & $(0.0000)^{* * *}$ & $(0.0257)^{*}$ & $(0.0002)^{* *}$ & $(0.0000)^{* * *}$ & \\
\hline
\end{tabular}

$* * *, * *, *$ Statistically significant at $1 \%, 5 \%$ and $10 \%$, respectively.

The variables are defined as follows. CHEPS. absolute value of the difference between the EPS of firm i in the current year $(\mathrm{t})$ and EPS in the prior year $(\mathrm{t}-1)$, deflated by the share price at the end of year $\mathrm{t}$; LNSIZE. logarithm of the market capitalisation of firm $i$ at the end of year t; TIME. time interval between analysts' forecasts of annual earnings and the date on which actual earnings are published; COV. number of analysts making forecasts for firm i in year t; AFE. absolute error in analysts' forecasts for firm i and year t, deflated by the share price at the end of year t; FSD. standard deviation in analysts' EPS forecasts for firm $i$ and year $t$, deflated by the share price at the end of year $\mathrm{t}$. 
Table 3

Descriptive statistics for analysts' forecast error and forecast dispersion variables by periods

\begin{tabular}{|c|c|c|c|c|c|c|c|}
\hline & Mean & Median & Max & Min & \multicolumn{2}{|c|}{ Std. Deviation } & Skewness \\
\hline \multicolumn{8}{|c|}{ Panel A. $A F E_{i, t}$ by period } \\
\hline Pretrans & 0.0290 & 0.0059 & 0.3526 & 0.0002 & \multicolumn{2}{|c|}{0.0723} & 3.9572 \\
\hline Trans & 0.0150 & 0.0053 & 0.3526 & 0.0001 & \multicolumn{2}{|c|}{0.0466} & 6.2190 \\
\hline Adopt & 0.0213 & 0.0063 & 0.3455 & 0.0001 & \multicolumn{2}{|c|}{0.0501} & 4.5841 \\
\hline Post1 2006 & 0.0129 & 0.0058 & 0.1130 & 0.0001 & \multicolumn{2}{|c|}{0.0209} & 3.1853 \\
\hline Post2 2007 & 0.0165 & 0.0065 & 0.1817 & 0.0000 & \multicolumn{2}{|c|}{0.0283} & 3.3303 \\
\hline \multicolumn{8}{|c|}{ Panel B. $F S D_{i, t}$ by period } \\
\hline Pretrans & 0.0172 & 0.0111 & 0.0966 & 0.0000 & \multicolumn{2}{|c|}{0.0193} & 2.5041 \\
\hline Trans & 0.0082 & 0.0061 & 0.0458 & 0.0000 & \multicolumn{2}{|c|}{0.0079} & 2.3604 \\
\hline Adopt & 0.0081 & 0.0055 & 0.0539 & 0.0000 & \multicolumn{2}{|c|}{0.0083} & 2.8953 \\
\hline Post1 2006 & 0.0076 & 0.0042 & 0.0568 & 0.0000 & \multicolumn{2}{|c|}{0.0101} & 3.0380 \\
\hline Post2 2007 & 0.0145 & 0.0069 & 0.1360 & 0.0000 & \multicolumn{2}{|c|}{0.0227} & 3.1972 \\
\hline \multicolumn{8}{|c|}{ Panel C. Univariant analysis: Difference of means and medians test } \\
\hline & \multicolumn{3}{|c|}{ AFE } & \multicolumn{4}{|c|}{ FSD } \\
\hline & $\mathrm{p}(\mathrm{t})$ & $\mathrm{p}(\mathrm{w})$ & & \multicolumn{2}{|c|}{$\mathrm{p}(\mathrm{t})$} & \multicolumn{2}{|c|}{$\mathrm{p}(\mathrm{w})$} \\
\hline Pretrans-Trans & $0.0780 *$ & \multicolumn{2}{|l|}{0.1100} & \multicolumn{2}{|c|}{$0.0004 * * *$} & \multicolumn{2}{|c|}{$0.0035^{* * *}$} \\
\hline Pretrans-Adopt & 0.3230 & \multicolumn{2}{|l|}{0.6900} & \multicolumn{2}{|c|}{$0.0003^{* * *}$} & \multicolumn{2}{|c|}{$0.0011 * * *$} \\
\hline Pretrans-Post1 2006 & $0.0360^{* *}$ & \multicolumn{2}{|l|}{0.3900} & \multicolumn{2}{|c|}{$0.0001 * * *$} & \multicolumn{2}{|c|}{$0.0000^{* * *}$} \\
\hline Pretrans-Post2 2007 & $0.0950^{*}$ & \multicolumn{2}{|l|}{0.5000} & \multicolumn{2}{|c|}{0.1928} & \multicolumn{2}{|c|}{0.1511} \\
\hline
\end{tabular}

$\mathrm{p}(\mathrm{t}), \mathrm{p}$-value for the parametric test of difference of means Student's t-test,

$\mathrm{p}(\mathrm{w}), \mathrm{p}$-value for the non parametric Wilcoxon difference of medians test

$* * *, * *, *$ Statistically significant at $1 \%, 5 \%$ and $10 \%$, respectively.

Panel A shows the descriptive statistics for the dependent variable AFE in the periods into which the sample is divided. Panel B shows the descriptive statistics for the dependent variable FSD in the periods into which the sample is divided. The variables are defined as follows. AFE. absolute error in analysts' earnings forecasts for firm $i$ and year $t$, deflated by the share price at the end of year t. FSD. standard deviation in analysts' EPS forecasts for firm $\mathrm{i}$ and year $\mathrm{t}$, deflated by the share price at the end of year t. Pre-trans is the pre-transition period (2003). Trans is the transition period (2004). Adopt refers to the adoption period (2005) when IFRS became mandatory and the first financial statements are prepared under IFRS. Post refers to the postadoption period 2006 and post-adoption period 2007. Panel C shows a univariant contrast of means and medians for the variables AFE y FSD. 


\section{Table 4}

Descriptive statistics for control variables $(\mathrm{N}=369)$

\begin{tabular}{|c|c|c|c|c|c|c|}
\hline & Mean & Median & $\operatorname{Max}$ & Min & Std. Deviation & Skewness \\
\hline \multicolumn{7}{|c|}{ Panel A. Pre-IFRS period } \\
\hline Cheps & 0.0582 & 0.0123 & 0.8958 & 0.0003 & 0.1611 & 4.3983 \\
\hline Cov & 12.7744 & 10.0000 & 45.0000 & 2.0000 & 9.7059 & 1.0372 \\
\hline Lnsize & 7.2028 & 7.3635 & 11.1373 & 3.8722 & 1.7014 & 0.1112 \\
\hline Time & 51.7819 & 55.0000 & 89.0000 & 12.0000 & 11.3139 & -1.2732 \\
\hline \multicolumn{7}{|c|}{ Panel B. Post-IFRS period } \\
\hline Cheps & 0.0382 & 0.0150 & 0.8958 & 0.0003 & 0.0801 & 6.4997 \\
\hline Cov & 11.5169 & 9.5000 & 40.0000 & 2.0000 & 8.3081 & 0.9365 \\
\hline Lnsize & 7.6344 & 7.6774 & 11.1396 & 3.8898 & 1.5982 & 0.0964 \\
\hline Time & 52.6483 & 57.0000 & 90.0000 & 6.0000 & 12.3039 & -1.7014 \\
\hline \multicolumn{7}{|c|}{ Panel C. Difference of means and medians test between IFRS pre and post-periods } \\
\hline & & \multicolumn{4}{|c|}{ P-values of different two-samples test } & \\
\hline & & $\mathrm{p}(\mathrm{t})$ & & $\mathrm{p}(\mathrm{w})$ & $\mathrm{p}(\mathrm{z})$ & \\
\hline Cheps & & 0.1818 & & 0.2197 & 0.2860 & \\
\hline Cov & & 0.2244 & & 0.3875 & 0.4477 & \\
\hline Lnsize & & $0.0106^{* *}$ & & $0.0357 * *$ & $0.0122^{* *}$ & \\
\hline Time & & 0.5256 & & $0.0418^{* *}$ & $0.0200 * *$ & \\
\hline
\end{tabular}

$\mathrm{p}(\mathrm{t}), \mathrm{p}$-value for the parametric test of difference of means Welch t-test,

$\mathrm{p}(\mathrm{w})$, $\mathrm{p}$-value for the parametric test of difference of means Yuen test (trimmed mean),

$\mathrm{p}(\mathrm{z}), \mathrm{p}$-value for the non parametric Wilcoxon difference of medians test

$* * *, * *, *$ Statistically significant at $1 \%, 5 \%$ and $10 \%$, respectively.

Panel A shows the descriptive statistics for the control variables used in the study on the pre-IFRS period (Pretrans and Trans periods). Panel B shows the descriptive statistics for the control variables used in the study on the post-IFRS period (Adopt and Post periods). CHEPS. absolute value of the difference between the EPS of firm $i$ in the current year $(t)$ and EPS in the prior year $(t-1)$, deflated by the share price at the end of year $\mathrm{t}$; COV. number of analysts making forecasts for firm $\mathrm{i}$ in year $\mathrm{t}$; LNSIZE. logarithm of the market capitalisation of firm $i$ at the end of year $t$ in millions of euros; TIME. time interval between analysts' forecasts of annual earnings and the date on which actual earnings are published; N. number of observations. Panel $\mathrm{C}$ show the p-values of different tests of mean and median for control variables between the IFRS preand post-adoption periods. 
Table 5

Multivariate regression analysis of the effects of mandatory IFRS adoption on analysts' forecast error

\begin{tabular}{lllll}
\hline & Coefficient & Std. Error & $t$-statistic & $\mathbf{P}>|\mathbf{t}|$ \\
\hline Constant & 0.0920 & 0.0170 & 5.4103 & 0.0000 \\
Trans & -0.0090 & 0.0070 & -1.2790 & 0.2017 \\
Adopt & -0.0083 & 0.0069 & -1.1893 & 0.2351 \\
Post1 & -0.0133 & 0.0070 & -1.8992 & $0.0583^{* *}$ \\
Post2 & -0.0148 & 0.0068 & -2.1792 & $0.0300^{* *}$ \\
Lnsize (-) & -0.0009 & 0.0013 & -0.7144 & 0.4754 \\
Loss (+) & 0.0193 & 0.0086 & 2.2254 & $0.0267^{* *}$ \\
Time (+) & 0.0000 & 0.0001 & 0.2837 & 0.7768 \\
Cov (-) & -0.0100 & 0.0042 & -2.3762 & $0.0180^{* *}$ \\
Cheps (+) & 0.0145 & 0.0015 & 9.4109 & $0.0000^{* * *}$ \\
Number of observations & 369 & & & \\
Adjusted R & $23.63 \%$ & & & \\
F-Statistic & 13.65 & & & \\
\hline
\end{tabular}

$* * *, * *, *$ Statistically significant at $1 \%, 5 \%$ and $10 \%$, respectively.

The estimated model is as follows.

$$
\begin{aligned}
& A F E_{i, t}=\beta_{0}+\beta_{1} \text { Trans }+\beta_{2} \text { Adopt }+\beta_{3} \text { Post } 1+\beta_{4} \text { Post } 2+\beta_{5} \text { Lnsize }_{i, t}+\beta_{6} \text { Loss } \\
& +\beta_{7} \text { Time }+\beta_{8} \operatorname{Cov}_{i, t}+\beta_{9} \text { Cheps }_{i, t}
\end{aligned}
$$

The variables are defined as follows. Extreme values have been winsorised at one standard deviation. AFE. absolute error in analysts' forecasts for firm $\mathrm{i}$ and year $\mathrm{t}$, deflated by the share price at the end of year $\mathrm{t}$; TRANS. dummy variable which takes a value of 1 for each observation in the year of transition to mandatory adoption of IFRS (2004) and zero otherwise; ADOPT. dummy variable which takes a value of 1 for each observation in the year of transition to mandatory adoption of IFRS (2005) and zero otherwise; POST1. dummy variable which takes a value of 1 for each observation in the year 2006 after mandatory adoption of IFRS and zero otherwise; POST2. dummy variable which takes a value of 1 for each observation in the year 2007 after mandatory adoption of IFRS and zero otherwise; LNSIZE. logarithm of the market capitalisation of firm $i$ at the end of year t; LOSS. dummy variable that takes a value of 1 if EPS for the current year is negative (loss-making firms) and zero otherwise; TIME. time interval between analysts' forecasts of annual earnings and the date on which actual earnings are published; COV. proxy for analyst coverage, measured as the unexplained residual part of size; CHEPS. logarithm of the absolute value of the difference between the EPS of firm $i$ in the current year $(t)$ and EPS in the prior year $(t-1)$, deflated by the share price at the end of year $t$. 
Table 6

Multivariate regression analysis of the effects of mandatory IFRS adoption on analysts' forecast dispersion

\begin{tabular}{|c|c|c|c|c|}
\hline & Coefficient & Std. Error & $t$-statistic & $P>|t|$ \\
\hline Constant & 0.0317 & 0.0053 & 5.9836 & 0.0000 \\
\hline Trans & -0.0066 & 0.0022 & -3.0197 & $0.0027 * *$ \\
\hline Adopt & -0.0081 & 0.0021 & -3.7547 & $0.0002 * * *$ \\
\hline Post1 & -0.0076 & 0.0022 & -3.5010 & $0.0005^{* * *}$ \\
\hline Post2 & -0.0029 & 0.0021 & -1.3908 & 0.1651 \\
\hline Lnsize (-) & -0.0009 & 0.0004 & -2.1679 & $0.0308^{* *}$ \\
\hline Loss (+) & 0.0171 & 0.0027 & 6.3430 & $0.0000 * * *$ \\
\hline Time (+) & 0.0000 & 0.0000 & 1.0930 & 0.2751 \\
\hline Cov (-) & -0.0025 & 0.0013 & -1.9420 & $0.0529 *$ \\
\hline Cheps (+) & 0.0031 & 0.0004 & 6.5775 & $0.0000 * * *$ \\
\hline Number of observations & 369 & & & \\
\hline Adjusted $\mathrm{R}^{2}$ & $30.75 \%$ & & & \\
\hline F-Statistic & 17.71 & & & \\
\hline
\end{tabular}

The estimated model is as follows.

$$
\begin{aligned}
F S D_{i, t}= & \beta_{0}+\beta_{1} \text { Trans }+\beta_{2} \text { Adopt }+\beta_{3} \text { Post } 1+\beta_{4} \text { Post } 2+\beta_{5} \text { Lnsize }_{i, t}+\beta_{6} \text { Loss } \\
& +\beta_{7} \text { Time }+\beta_{8} \operatorname{Cov}_{i, t}+\beta_{9} \text { Cheps }_{i, t}
\end{aligned}
$$

The variables are defined as follows. Extreme values have been winsorised at one standard deviation. FSD. standard deviation in analysts' EPS forecasts for firm i and year $t$, deflated by the share price at the end of year t; TRANS. dummy variable which takes a value of 1 for each observation in the year of transition to mandatory adoption of IFRS (2004) and zero otherwise; ADOPT. POST1. dummy variable which takes a value of 1 for each observation in the year 2006 after mandatory adoption of IFRS and zero otherwise; POST2. dummy variable which takes a value of 1 for each observation in the year 2007 after mandatory adoption of IFRS and zero otherwise; LNSIZE. logarithm of the market capitalisation of firm $i$ at the end of year t; LOSS. dummy variable that takes a value of 1 if EPS for the current year is negative (loss-making firms) and zero otherwise; TIME. time interval between analysts' forecasts of annual earnings and the date on which actual earnings are published; COV. proxy for analyst coverage, measured as the unexplained residual part of size; CHEPS. logarithm of the absolute value of the difference between the EPS of firm $i$ in the current year $(\mathrm{t})$ and EPS in the prior year $(\mathrm{t}-1)$, deflated by the share price at the end of year $\mathrm{t}$. 
Table 7

Sensitivity analysis of the impact of mandatory IFRS adoption on analysts' forecast error and dispersion by separating firms audited by one of the Big 4 auditors and those audited by other (nonBig 4) auditors.

Panel A. AFE

Panel B. FSD

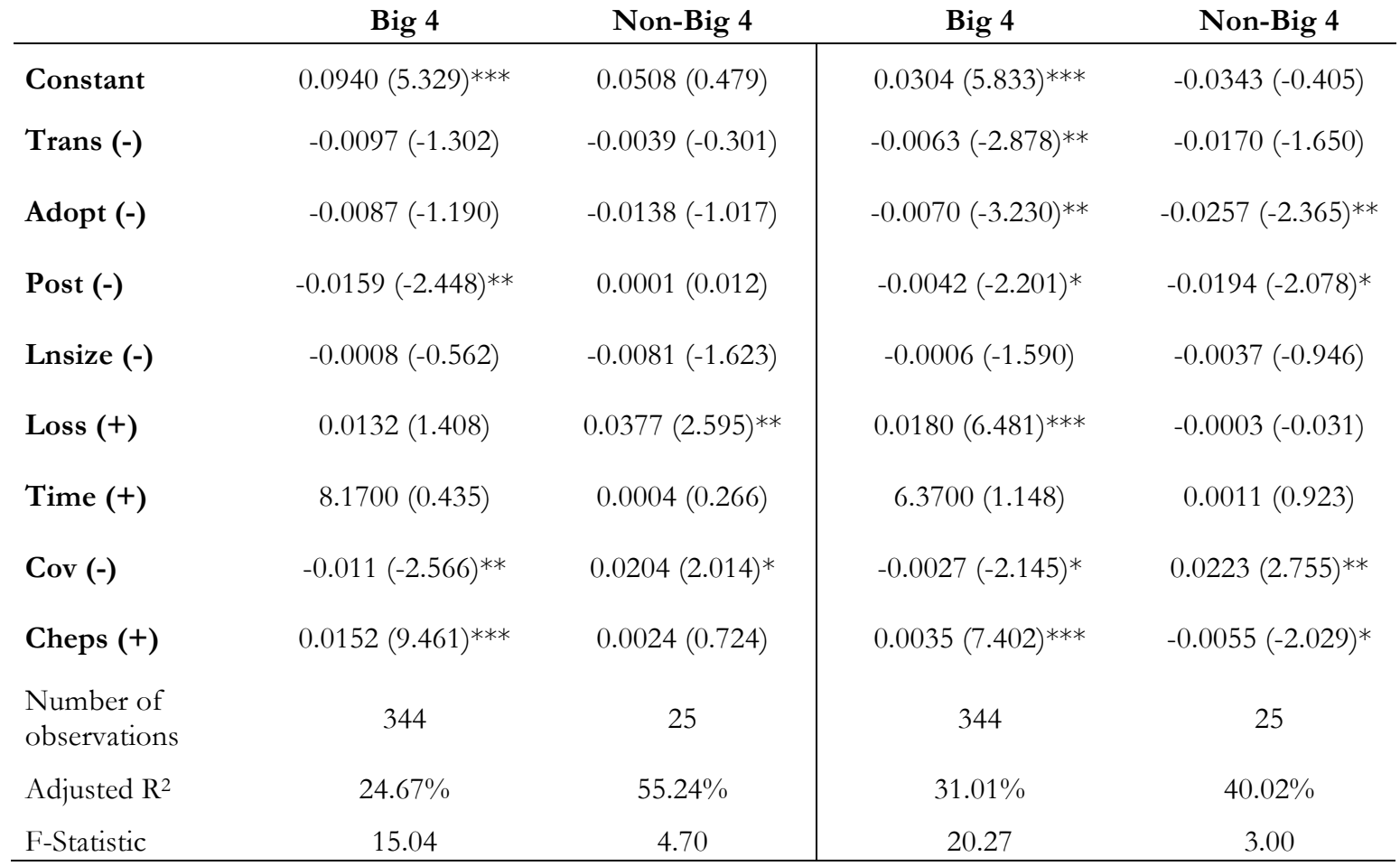

$* * *, * *, *$ Statistically significant at $1 \%, 5 \%$ and $10 \%$, respectively.

The following models are estimated.

$$
\begin{aligned}
& A F E_{i, t}=\beta_{0}+\beta_{1} \text { Trans }+\beta_{2} \text { Adopt }+\beta_{3} \text { Post }+\beta_{4} \text { Lnsize }_{i, t}+\beta_{5} \text { Loss }+\beta_{6} \text { Time }+\beta_{7} \text { Cov }_{i, t}+\beta_{8} \text { Cheps }_{i, t} \\
& F S D_{i, t}=\beta_{0}+\beta_{1} \text { Trans }+\beta_{2} \text { Adopt }+\beta_{3} \text { Post }_{+} \beta_{4} \text { Lnsize }_{i, t}+\beta_{5} \text { Loss }+\beta_{6} \text { Time }+\beta_{7} \text { Cov }_{i, t}+\beta_{8} \text { Cheps }_{i, t}
\end{aligned}
$$

The variables are defined as follows. Extreme values have been winsorised at one standard deviation. AFE. absolute error in analysts' forecasts for firm i and year $t$, deflated by the share price at the end of year t; FSD. standard deviation in analysts' EPS forecasts for firm $\mathrm{i}$ and year $\mathrm{t}$, deflated by the share price at the end of year t; BIG 4. the auditor is one of the Big 4; NON-BIG 4. the auditor is not one of the Big 4; TRANS. dummy variable which takes a value of 1 for each observation in the year of transition to mandatory adoption of IFRS (2004) and zero otherwise; ADOPT. dummy variable which takes a value of 1 for each observation in the year of transition to mandatory adoption of IFRS (2005) and zero otherwise; POST. dummy variable which takes a value of 1 for each observation in the years after mandatory adoption of IFRS (2006 and 2007) and zero otherwise; LNSIZE. logarithm of the market capitalisation of firm $i$ at the end of year t; LOSS. dummy variable that takes a value of 1 if EPS for the current year is negative (loss-making firms) and zero otherwise; TIME. time interval between analysts' forecasts of annual earnings and the date on which actual earnings are published; COV. proxy for analyst coverage, measured as the unexplained residual part of size; CHEPS. absolute value of the difference between the EPS of firm $i$ in the current year $(t)$ and EPS in the prior year ( $t-1)$, deflated by the share price at the end of year $t$. 